\title{
ANALISA PEMROSESAN PARALEL UNTUK KOMPRESI DAN DEKOMPRESI DATA
}

\author{
Wilhelmus Wajo Kelen, Dwi Nugraheny \\ Program Studi Teknik Informatika \\ Sekolah Tinggi Teknologi Adisutjipto Yogyakarta \\ informatika(a),stta.ac.id
}

\begin{abstract}
Parallel processing system is a collection of computers connected and work together as an integrated computer resources to complete certain jobs which are connected by the network, so it can be seen as one-unity. Parallel processing can be applied to such work compress and decompression the data. Compression processis away to compress the data so that it requires less storage space, while the decompression process is the process of restoring data to its original shape. The utilization of parallel processing to speed up or get more speed on the efficiency of the data compression so the job. The work came to be divided to parallel computers that are not doing the work.
\end{abstract}

Keywords : parallel processing, compression, speedup

\section{Pendahuluan}

Perkembangan teknologi processor sebagai perangkat keras komputer telah mengalami peningkatan yang sangat signifikan, hal ini terjadi seiring dengan penyelesaian masalah yang sangat kompleks. Meskipun kecepatan processor dapat ditingkatkan terus namun karena terbatasnya sumber daya yang ada, tentu ada suatu batas kecepatan yang tak mungkin lagi dapat dilewati. Oleh karena itu, pemrosesan paralel menjadi sebuah pilihan yang dapat mengatasi berbagai masalah dan keterbatasan terhadap komputasi yang tinggi. Dengan adanya pemrosesan paralel menjadikan komputasi dua atau lebih tugas dengan waktu bersamaan dapat menjadi lebih singkat. Dengan demikian, teknologi ini dapat diterapkan untuk pekerjaan yang tidak mempunyai komputer dengan processor yang cepat untuk melakukan sebuah pekerjaan yang besar salah satunya kompresi dan dekompresi data.

\section{Kajian Pustaka}

Wintolo, Hero (2010) Deteksi Kinerja Prosessor Komputer Client Dengan Cara Remote Untuk Mendukung Aplikasi Pemrosesan Paralel menerangkan bahwa semua instruksi dan proses dalam komputer dikerjakan oleh prosessor komputer tersebut.

Rijayana, Iwan (2005) Teknologi Load Ballance Untuk Mengatasi Beban Server menerangkan bahwa Load Ballance atau penyeimbangan beban dalam jaringan sangat penting bila skala dalam jaringan komputer makin besar demikian juga traffic data yang ada dalam jaringan komputer makin lama makin tinggi.

\section{Metode Penelitian}

\subsection{Kompresi dan Dekompresi}

Kompresi berarti memampatkan atau mengecilkan ukuran. Kompresi data adalah proses mengkodekan informasi menggunakan bit atau information-bearing unit yang lain yang lebih rendah daripada representasi data yang tidak terkodekan dengan suatu sistem encoding tertentu. Proses pembalikan data yang sudah dikompres menjadi data seperti semula disebut dekompresi (decompression). Stream data dapat digunakan sebagai istilah untuk menunjukan sebuah proses 
pembacaan atau penulisan data dari atau ke sebuah file atau dari sebuah buffer dalam memory komputer.

\subsection{Grid Computing}

Grid computing merupakan sistem computer dengan sumber daya yang dikelola dan dikendalikan secara lokal. Dimana sumber daya ini berbeda dalam hal kebijakan dan mekanisme yaitu mencakup sumber daya komputasi dikelola oleh sistem batch berbeda, sistem storage berbeda pada node berbeda. Kebijakan berbeda dipercayakan kepada useryang sama pada sumber daya berbeda pada grid. Grid computing memiliki sifat alami dinamis artinya sumber daya dan pengguna dapat sering berubah selain itu.

\subsection{Analisa Dan Perancangan}

\subsubsection{Perancangan Jaringan}

Analisa perancangan dan pengembangan jaringan yang berbasis pemrosesan paralel terlebih dahulu dibuat dalam suatu simulasi menggunakan packettracer untuk memudahkan peneliti. Hal ini dilakukan untuk mengurangi kesahalan seperti menentukan switch yang digunakan ataupun pemberian IP Address. Pada jaringan local AreaNetwork yang berbasis pemrosesan paralel pemberian IPAdddres dilakukan secara manual (statis), selanjutnya komputer pada jaraingan paralel ini akan dihubungakan oleh media transmis berupa kabel UTP dengan switch. Switch yang berfungsi sebagai manajemen trafik untuk proses pembagian data untuk kompresi atau dekompresi dari webserver yang menyediakan layanan dari komputer client.

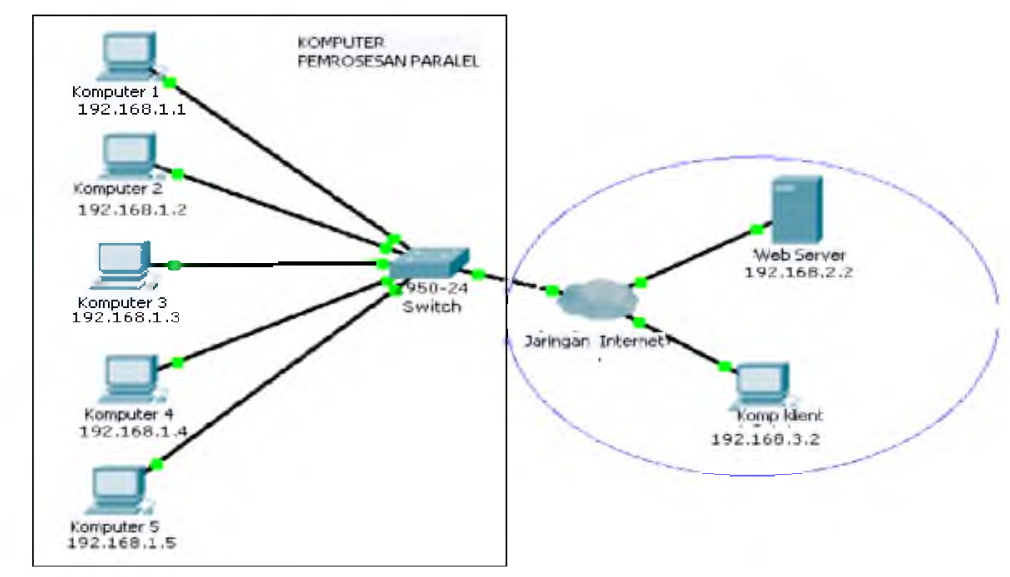

Gambar 1 Perancangan Jaringan

\subsubsection{Diagram Alur Data Aplikasi Gridzip}

Secara keseluruhan aplikasi Gridzip mempunyai dua entitas, yaitu admin dan client. Admin dan client mempunyai akses yang berbeda terhadap Aplikasi Gridzip tersebut 


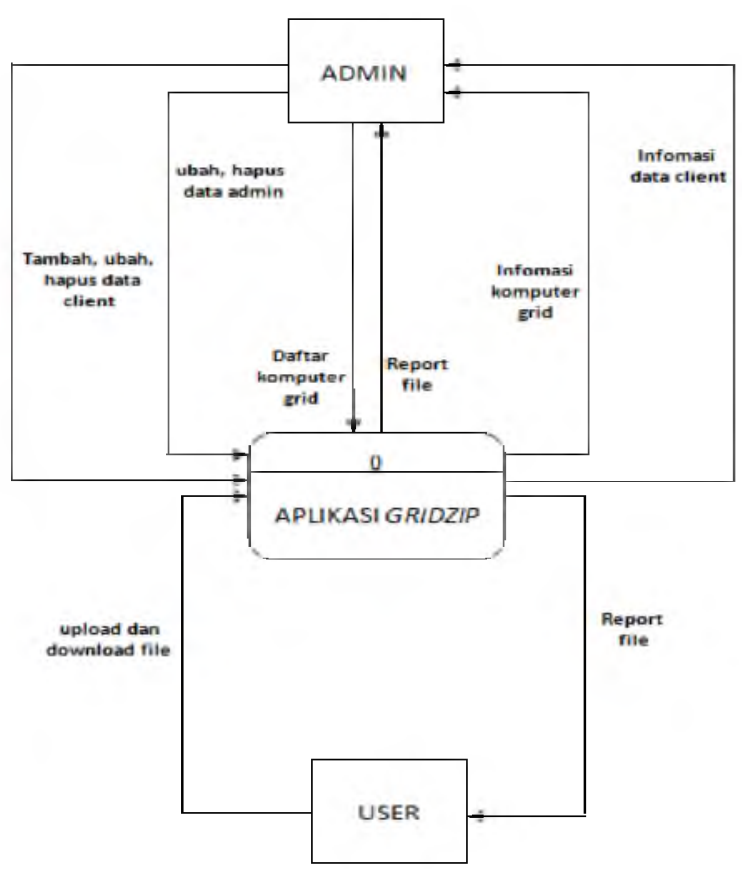

Gambar 2 Diagram Alur Data Aplikasi Gridzip

Diagram konteks pada aplikasi Gridzip terdiri dari Admin dan User yang mempunyaiaktifitas yang berbeda. User tidak memiiki akses penuh seperti Admin. Semua Manajemen dilakukan User, File dan grid computing dilakukan oleh admin.

\subsubsection{Flowchart System Aplikasi Gridzip}

Pada aplikasi yang dikembangkan terlebih dahulu dibuat sebuah flowchart yang dapat memudahkan dalam coding atau penulisan scrip program. Aplikasi Gridzip untuk melakukan kompresi dan dekompresi data dirancang dalam suatu flowchartsystem untuk menentukan proses selanjutnya.

Pada flowchart dapat diketahui bahwa user mengupload file ke webserver, file tersebut akan diolah oleh sistem yakni sistem akan mengirim file tersebut ke dalam database dan sistem juga akan mencari komputer grid yang tidak bekerja untuk diolah (proses kompresi dan dekompresi). File hasil olahan tersebut disimpan di komputer grid tersebut dan reportfile akan dikirim kembali ke sistem dan diteruskan ke database untuk disimpan. 


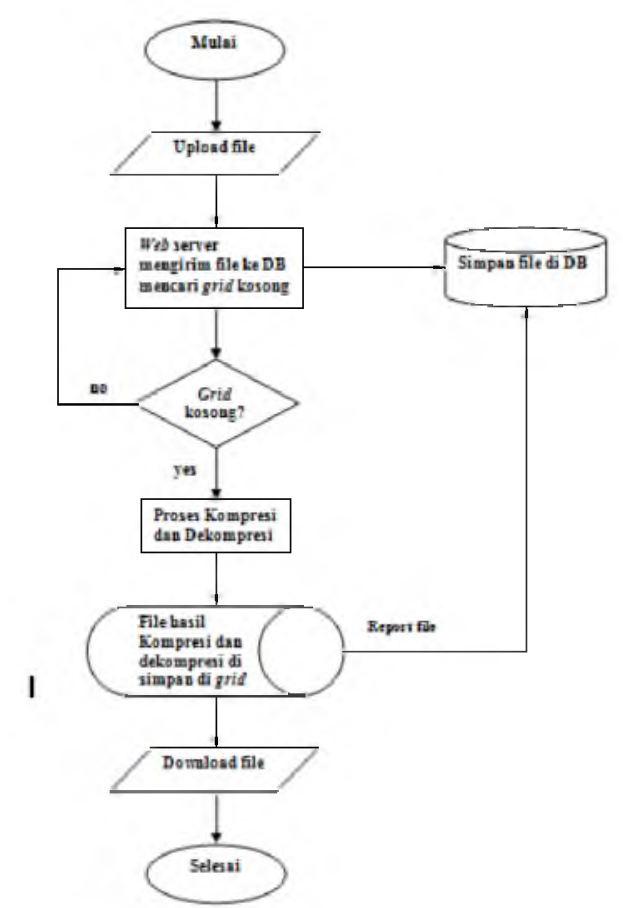

Gambar 3 Flowchart System Aplikasi Gridzip

\section{Hasil Dan Pembahasan}

\subsection{Pengujian Sitem Komputer Tunggal}

Pengujian di sebuah PC atau komputer tunggal, aplikasi tambahan yang digunakan adalah aplikasi Winrar 4.20. Aplikasi ini mengkompresikan data yang sama, yang digunakan juga oleh Grid Computing.

Tabel 1. Pengujian Pada Sistem Komputer Tunggal

\begin{tabular}{|l|l|r|l|r|r|}
\hline No. & \multicolumn{1}{|c|}{ Nama File } & Ukuran $(\mathrm{Kb})$ & Nama zip & Ukuran $(\mathrm{Kb})$ & $\begin{array}{c}\text { Waktu } \\
(\text { Second })\end{array}$ \\
\hline 1. & Secret Acces.mkv & 366.662 & Secret Acces.rar & 349.231 & 1.357 \\
\hline 2. & Tom and Jerry.mkv & 636.812 & Tom and Jerry.rar & 628.726 & 2.016 \\
\hline 3. & Photoshop CS5.nrg & 757.039 & Photoshop CS5.rar & 947471 & 3.871 \\
\hline 4. & MS. Office 2007.nrg & 1.047 .990$. & MS. Office 2007.rar & 947471 & 5.187 \\
\hline 5. & the Malficient.mkv & 1.432 .571 & the Malficient.rar & 1260923 & 7.038 \\
\hline
\end{tabular}

Dari tabel 1 dapat diketahui bahwa sebuah file yang akan di kompresi dengan aplikasi Winrar dengan kapasitas dan format file yang berbeda. Sebuah file "Tom dan Jerry.mkv" dengan ukuran asli $636.812 \mathrm{~Kb}$ setelah dikompresi dengan aplikasi Winrar, ukurannya akan berubah menjadi $628.726 \mathrm{~Kb}$ dengan kecepatan 2.016second.

\subsection{Pengujian Sistem Grid Computing}

Pengujian Aplikasi Gridzip unuk menentukan kecepatan dalam kompresi data. Aplikasi diujicobakan pada jaringan local dengan mengunakan 3 komputer sebagai Grid. 


\begin{tabular}{|c|c|c|c|c|c|c|c|}
\hline 3 & BAB_I_PENDAHULUAW,doळ & 21129 & $\begin{array}{l}2014-08-20 \\
18: 43: 18\end{array}$ & BAB_I_PENDAHULUAN, doס.zip & 18434 &, 031200170516968 & 2 \\
\hline 4 & 3-LOGIKA-pp: & 472576 & $\begin{array}{l}2014-08-20 \\
18: 43: 31\end{array}$ & 3-LOGIKA.pptzip & 300298 & ,31200003623962 & 3 \\
\hline 5 & 11-Kuantor.ppt & 1090048 & $\begin{array}{l}2014-08-20 \\
18: 43: 52\end{array}$ & 11-Kuantor.ppt.zip & 988707 & 46800088882446 & 1 \\
\hline 6 & Kuantor.ppt & 1090048 & $\begin{array}{l}2014-08-21 \\
04: 08: 35\end{array}$ & Kuantor.ppt.zip & 988701 & .57720112800598 & 3 \\
\hline 7 & 03._Anak_Cerdas.wmw & 1609165 & $\begin{array}{l}2014-08-21 \\
04: 26: 29\end{array}$ & 03._Anak_Cerdas,wmy,zip & 1321545 & 45240092277527 & 2 \\
\hline
\end{tabular}

Gambar 4. Analisa Hasil Kompresi dengan Aplikasi Gridzip

\subsection{Hasil Pengujian pada Kompresi Data}

Analisa Speed up sistem komputer tunggal ditemukan kecepatan yang semakin lama, ketika data yang dikompresi banyak dan berukuran besar. Hal ini berbanding terbalik dengan system Grid Computing yang tetap stabil dalam melakukan kompresi data dalam jumlah banyak dan berukuran besar. Karena file akan dibagikan kebeberapa komputer grid untuk melakukan proses kompresi. Untuk analisa selanjutnya penulis membandingkan dua tabel pada aktifitas di komputer tunggal dan komputer dengan sistem grid.

Tabel 2. Waktu Speed up Sistem Komputer Tunggal

\begin{tabular}{|r|l|r|r|}
\hline no & \multicolumn{1}{|c|}{ Nama zip } & Ukuran (Kb) & $\begin{array}{c}\text { Waktu kompres } \\
\text { (Second) }\end{array}$ \\
\hline 1 & Secret Acces.rar & 349.231 & 1.357 \\
\hline 2 & Tom and Jerry.rar & 628.726 & 2.016 \\
\hline 3 & Ubuntu 14.04 LTS.rar & 705223 & 2.914 \\
\hline 4 & Photoshop CS5.rar & 947471 & 3.871 \\
\hline 5 & MS. Office 2007.rar & 947471 & 5.187 \\
\hline 6 & the Malficient.rar & 1260923 & 7.038 \\
\hline
\end{tabular}

Pada tabel 2 diketahui kecepatan selama file dikompresi oleh sebuah komputer tunggal. Setelah dilakukan ujicoba pada sistem komputer tungggal akan dibandingkan dengan sistem grid computing. Unuk melihat waktu kecepatan pada komputer tunggal dapat dilihat pada gambar Grafik Waktu Pemrosesan Tunggal

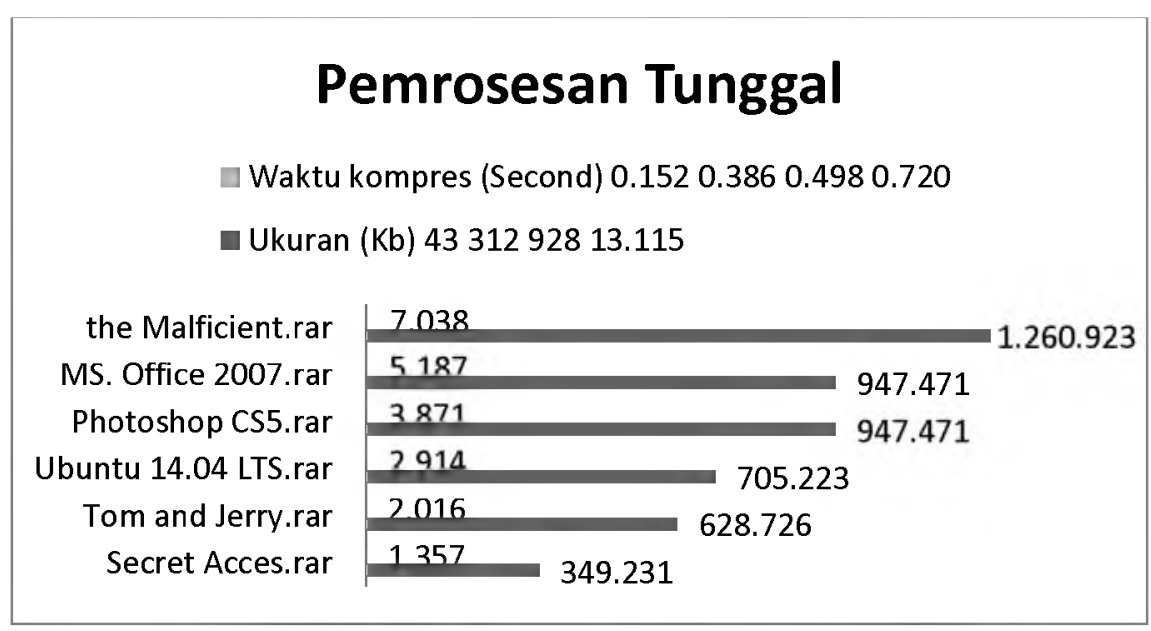

Gambar 5. Grafik Waktu Pemrosesan Tunggal 
Dari gambar 5 dapat diketahui bahwa dengan pemrosesan tunggal untuk kompresi file dengan ukuran yang besar maka dibutuhkan waktu yang lebih lama. File dengan nama "the Malficient.rar" dengan kapasitas file 1.260.923 dibutuhkan waktu untuk kompresi selama 7,038 second.

Untuk dapat membandingkan kecepatan antara pemrosesan tunggal dan pemrosesan dengan metode grid computing dapat dilihat pada tabel 3 dimana file yang sama yang dikompresi oleh komputer tunggal dijadikan ujicoba pada pemrosesan dengan grid computing.

Tabel 3. Waktu Speed Up Sistem Komputer Grid

\begin{tabular}{|r|l|r|r|}
\hline No & \multicolumn{1}{|c|}{ Nama zip } & Ukuran (Kb) & $\begin{array}{c}\text { Waktu kompres } \\
\text { (Second) }\end{array}$ \\
\hline 1. & Secret Acces.mkv.rar & 349.231 & 1.128 \\
\hline 2. & Tom and Jerry.mkv. rar & 628.726 & 1.845 \\
\hline 3. & Ubuntu 14.04 LTS.nrg.rar & 705.223 & 2.429 \\
\hline 4. & Photoshop CS5.nrg.rar & 947.471 & 3.201 \\
\hline 5. & MS. Office 2007.nrg.rar & 947.471 & 4.190 \\
\hline 6. & the Malficient.mkv.rar & 1.260 .923 & 5.521 \\
\hline
\end{tabular}

Setelah dilakukan ujicoba yang dapat dilihat pada tabel 3 maka dapat dihitung kecepatan atau speed up dan nilai efisiensi dari pemrosesan paralel. Pada ujicoba ini penggunaan 1 buah grid diartikan dengan 1 buah prosesor. Dimana komputer yang digunakan untuk uji coba merupakan komputer koheren.

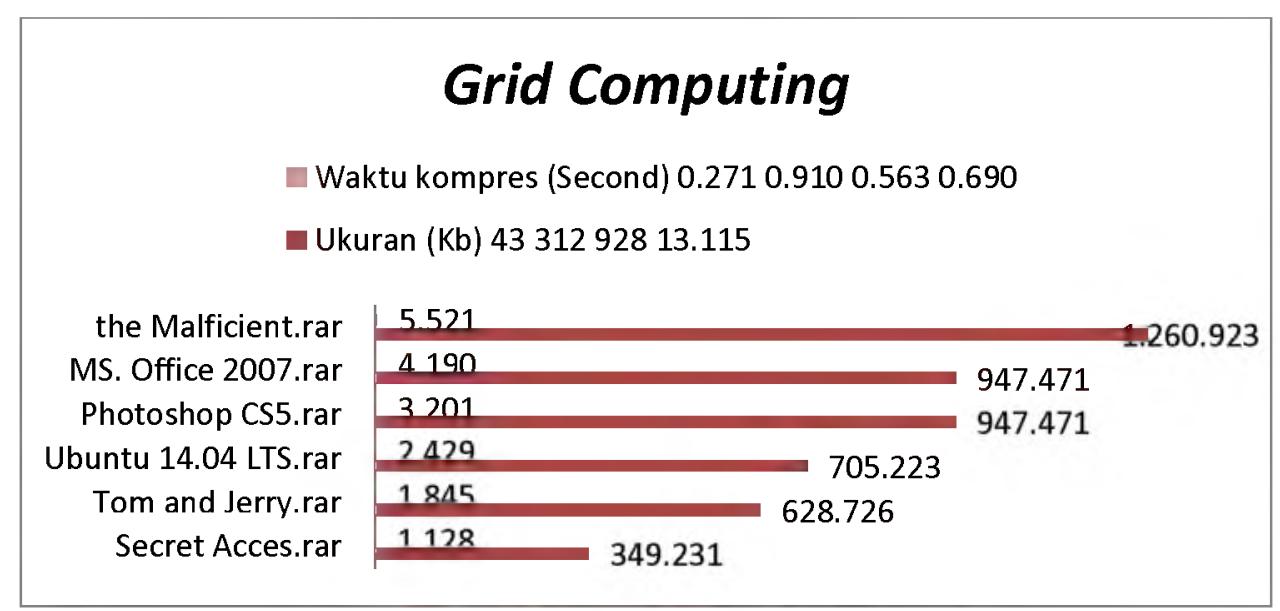

Gambar 6. Grafik Waktu GridComputing

Setelah dilakukan ujicoba yang dapat dilihat pada gambar 6 maka dapat dihitung kecepatan atau speed up dan nilai efisiensi dari pemrosesan paralel. Pada ujicoba ini penggunaan 1 buah grid diartikan dengan 1 buah prosesor. Dimana komputer yang digunakan untuk uji coba merupakan komputer koheren. 


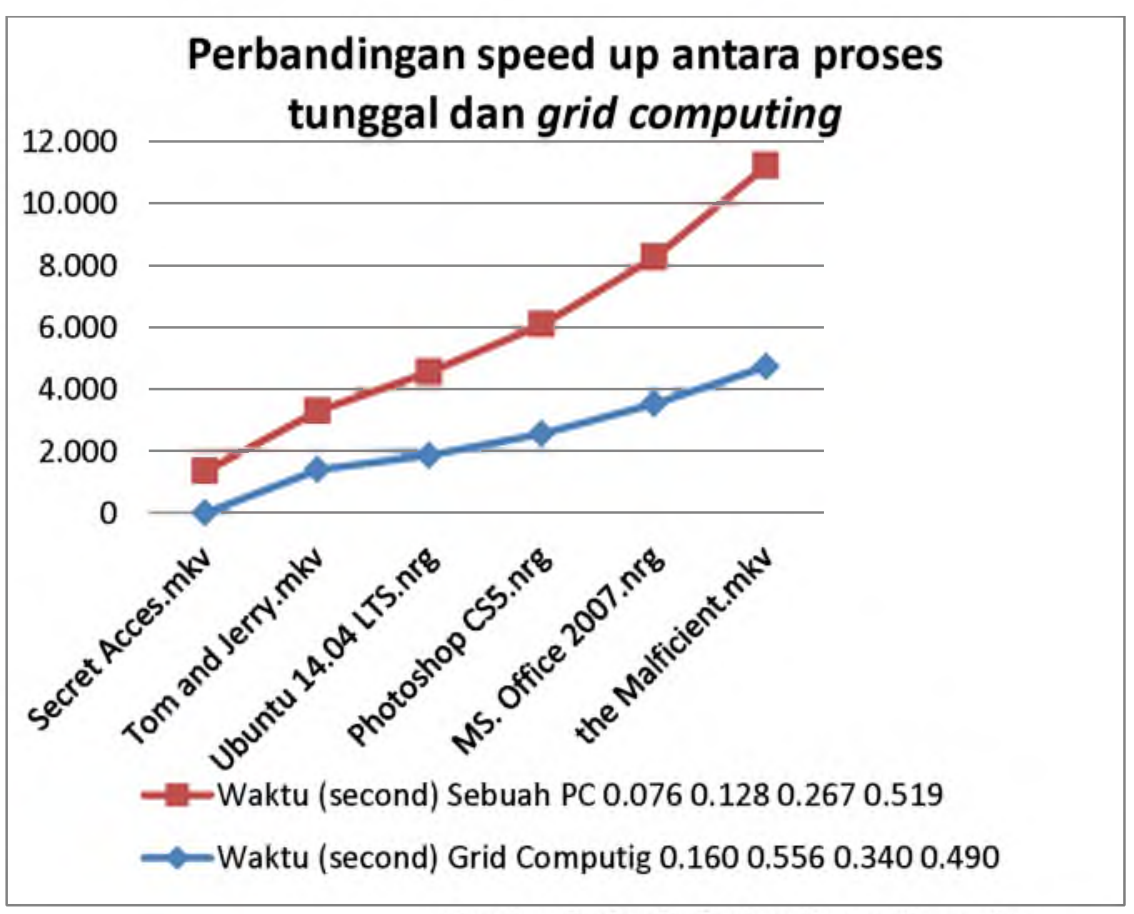

Gambar 7. Grafik Perbandingan Speed Up

Pada gambar7 diatas dapat dilihat bahwa dengan menggunakan pemrosesan tunggal akan kecepatan yang dibutuhkan untuk melakukan kompresi akan semakin lama dengan kapasitas file yang besar. Dari grafik diatas kecepatan dengan grid computing lebih stabil ketika data yang diolah dengan kapasitas yang lebih besar.

\subsection{Hasil Pengujian pada Dekompresi Data}

Tabel 4.Analisa Speed Up dan Efisiensi Grid Computing

\begin{tabular}{|c|c|c|c|c|c|}
\hline \multirow[b]{2}{*}{ No } & \multirow[b]{2}{*}{ Nama File } & \multicolumn{2}{|c|}{ Waktu (second) } & \multirow[b]{2}{*}{ Speed up } & \multirow[b]{2}{*}{ Efisiensi } \\
\hline & & Grid Computig & Sebuah PC & & \\
\hline 1. & Secret Acces.mkv & 0.797 & 1.357 & 1.702 & 0.353 \\
\hline 2. & Tom and Jerry.mkv & 1.404 & 1.894 & 1.349 & 0.449 \\
\hline 3. & Ubuntu 14.04 LTS.nrg & 1.878 & 2.691 & 1.432 & 0.477 \\
\hline 4. & Photoshop CS5.nrg & 2.560 & 3.532 & 1.379 & 0.459 \\
\hline 5 . & MS. Office 2007.nrg & 3.529 & 4.742 & 1.344 & 0.448 \\
\hline 6. & the Malficient.mkv & 4.750 & 6.483 & 1.365 & 0.455 \\
\hline
\end{tabular}

Dari ujicoba yang terlihat pada tabel 4 diketahui bahwa gridcomputing memiliki kecepatan yang lebih dari pada komputer tunggal. Sebuah file "Photoshop CS5.nrg" dengan ukuran $947.471 \mathrm{~Kb}$, file didekompresi dengan komputer tunggal memiliki kecepatan 3.532 second, sedangkan pada sistem gridcomputing memiliki kecepatan 2.560 second, sehingga nilai efisiensi adalah 0.459 . 


\section{Speed Up Dekompresi Data}

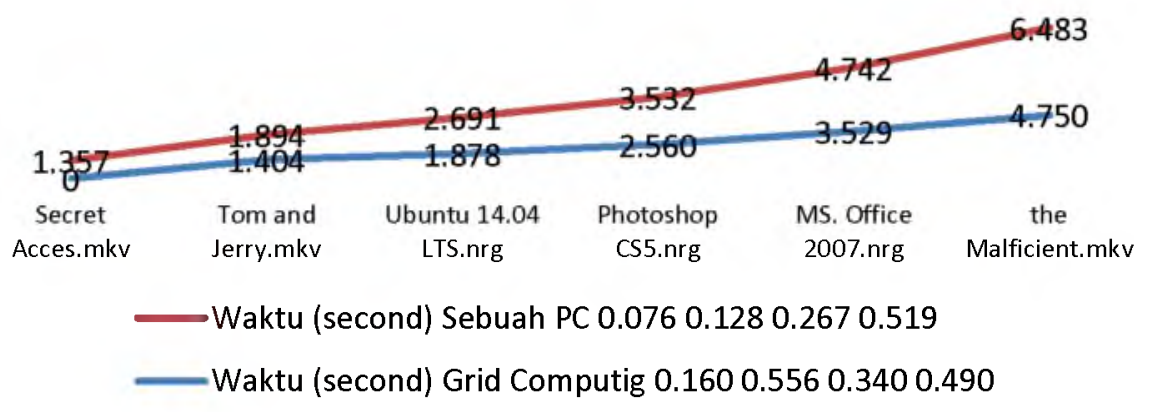

Gambar 8.Speed Up pada Proses Dekompresi Data

Dari grafik pada gambar8 dapat diketahui bahwa kapasitas file diatas dari 349.231 akan mengalami proses dekompresi yang lebih lama pada pemrosesan tunggal. Grafik diatas menunjukan proses dengan grid computinglebih stabil dalam hal ini tidak membutuhkan waktu yang lebih lama untuk kompresi data. Untuk menghitung speed updigunakan rumus speed up. Kecepatan pada komputer tunggal dibagi dengan kecepatan pada grid computing. Menghitung sebuah file "the Malficient.mkv" dengan kapasitas file $1.260 .923 \mathrm{~Kb}$.

\section{Penutup}

\subsection{Kesimpulan}

Setelah melalui tahap pengujian aplikasi pada jaringan local dan jaringan internet maka dapat disimpulkan:

1. Kompresi data dapat lebih cepat dengan sistem pemrosesan paralel yang diterapkan pada model Grid Computing.

2. Kompresi data dapat dilakukan pada jaringan local yang disebut jaringan LAN dan jaringan internet.

3. Kompresi data dengan Aplikasi Gridzip memiliki efisiensi lebih pada kecepatan (speed up).

4. Hasil pengujian maka dapat dikatakan bahwa aplikasi yang dibuat layak untuk dipakai.

\subsection{Saran}

Setelah melalui tahapan pengujian aplikasi, maka saran yang dapat disampaikan untuk pengembangan aplikasi ini selanjutnya adalah:

1. Aplikasi yang diterapkan selanjutnya ditambahkan loadbalancing pada pemrosesan paralel untuk pemerataan prosessor.

2. Pengembangan aplikasi yang berbasis multi OS (operation system) untuk proses kompresi dan dekompresi berbasis gridcomputing.

\section{Daftar Pustaka}

Clement Salome, Pottle Brian, Singh, 2010, Oracle Database : SQL Fundamentals I, Oracle, Edition 1.0.

Hero Wintolo, 2010, Deteksi Kinerja Prosesor komputer client dengan cara remote untuk mendukung aplikasi pemrosesan parallel, Sekolah Tinggi Teknologi Adisutjipto Yogyakarta, Angkasa, Volume 2.

Hero Wintolo, 2011, Design Of Parallel Processing applications With The Remote Execution, Sekolah Tinggi Teknologi Adisutjipto Yogyakarta, Angkasa,Volume 3.

Raharjo Budi, 2011, Belajar Otodidak Pemrograman Web Dengan PHP + Oracle, Informatika 
Syafisal Melvin, 2005, Pengantar Jaringan Komputer, Andi Publisher.

Wilikison Barry \& Allen Michael, 2010, Parallel Programming, Andi Offset.

http://www.databasedesign.co.uk/bookdatabasesafirstcourse/chap3/chap3.htm. 11:27, 20 Juli 2014.

http://getbootstrap.com/ 11:36, 27 Juli 2014.

http://www.jaringankomputer.org/macam-macam-jaringan-komputer/. 10:23, 05 Agustus 2014

http://php.net/manual/en/, 11:37, 10 Agustus 2014. 
Wilhelmus Wajo Kelen, Dw Nugraheny 